reconceptualized and a new book to reflect current approaches to Chinese art will be produced.

Stacey Pierson

ENDŌ ORIE:

A Cultural History of Japanese Women's Language.

(Michigan Monograph Series in Japanese Studies.) vii, 139 pp. Ann Arbor: Center for Japanese Studies, University of Michigan, 2006. \$38. ISBN 9781929280391.

Orie Endō's well-known abhorrence of a normative and inevitably ideological notion of "women's speech" surfaces vividly in A Cultural History of Japanese Women's Language (an English translation of the 1997 Onna no kotoba no bunkashi, Gakuyoo Shoboo, Tokyo). A female linguist investigating the nature of, and the discourse on, women's speech in literature, plays, press, governmental agency surveys, advertising, as well as in ostensibly scientific literature, Endō is confronted by a deluge of rather provocative material commentators being typically male, and prescriptivism a more common currency than rigorous description. But Endō's objective is not limited to the rectification of received ideas about the nature of "women's language". She goes much further and challenges the common-sense, yet essentialist, notion that women's speech has always been there because it naturally embodies female nature.

Endō's deconstructive project starts out with an attempt to identify documented evidence of specific realizations of gendered speech, in the earliest literary texts and other surviving documents. In the Kojiki, the oldest Japanese chronicle written in the Nara period (710-794), the first utterance of the god Izanagi no Mikoto and the goddess Izanami no Mikoto upon meeting each other is a completely undifferentiated exclamation of mutual appreciation. But the goddess speaks first, which vitiates the success of the Japanese archipelago's creation; only after reversing the order of speech is the task achieved. The episode announces two broad themes of the book: the lack of evidence of a definite speech differentiation in ancient times, and males' early preoccupation with dominance. Even during the Heian Period (794-1185), the rare references to gendered differences concern neither vocabulary nor grammar, but rather women's "manner of speech", i.e. their attitude, the use of emphasis, the speed and logic of their speech. However, it is in the following Kamakura (1185-1333) and Muromachi (1336-1573) periods that crucial developments take place. Endō acknowledges revisions of the accepted view that medieval Japan has been a time of systematic oppression of women, and is careful to avoid unqualified statements that link such new developments to an absolute and universal transformation of gender roles in this period. But she notes, for example, that while the asymmetrical use of honorifics does not unambiguously index gender (but rather class or age) gender begins, in this period, to be marked in a way that mirrors subordination in class and age, and submits that the rationale for this development lies in the rise of the samurai's political power and the escalation of male-dominated discourse. The birth of nyoobo kotoba (or language of the nyoobo, daughters of nobility and intellectuals attending at court) is characterized as a linguistic innovation that indexed demeanour rather than deference. As a type of argot, this marks in-group communication, based on the use of devices of indirect, euphemistic, 
metaphorical reference. Interestingly though, together with prefixation by $o$ (e.g. $y u>o-y u$ for "hot water"), which survived in the modern repertoire of honorific language, other devices such as abbreviation (takenoko $>$ take, "bamboo shoot") or repetitions (kazunoko > kazukazu, "herring roe") are also associated with childish language: what started as mother-talk may have come additionally to index femininity.

During the Edo period, a plethora of etiquette books appear which further polarize gendered linguistic conduct and produce exceptionally explicit normative codifications. Women are expected to speak softly and gently, avoid expressions of Chinese or popular origin (i.e. both "high" and "low" registers), or in fact speak as little as possible.

Several studies address the discourse on women's linguistic corruption in modern times (see for example M. Inoue, "What does language remember?: Indexical inversion and the naturalized history of Japanese women", Journal of Linguistic Anthropology, 14/1, 2004: 39-56), and Endō's account is largely consistent with these, but the chapters covering the Meiji period to the present are an excellent review of primary sources illustrating the innumerable contradictions that such discourse contained.

Despite modernization and the fostering of women's education, the promotion of "good wives and wise mothers" meant that normative linguistic codes saw little change. If anything, Japan's male academics can list another evil influence poisoning Japanese women's speech: Western women's intellectual assertiveness. The rebellious modan gaaru (modern girl) of early Showa was not a suitable model for the supportive role demanded of women during the war, and was expected to speak "haltingly" and act "bashfully". Even women's return to public spheres of social and intellectual life at the end of the war did not grant them the right of use of intellectual tools. It is not in the $1960 \mathrm{~s}$, nor the $70 \mathrm{~s}$ or $80 \mathrm{~s}$, but only the mid-1990s that finally attest to a novel acceptance of the language of diversity.

On the basis of abundant linguistic data and social commentaries, the book argues that the polarization of male and female language historically served the social, metapragmatic function of establishing and maintaining gender inequality - prescriptions on the rights of use of Chinese-based words would make little sense were these words not frequent in the lexicon of knowledge and academia (a contrast which thus can index progress vs tradition). Bemoaning women's use of slang (deplored when borrowed "upward" or mocked when borrowing "downward") suggests anxiety towards social mobility. But the book's main thesis is that the so-called "women's language" is the product of historical amnesia: it has not always been there, it is artificially construed as homogeneous, is positively driven by social inequality, and is then arbitrarily coded as "natural" and inherent to femininity. Moreover, it is subject to reinterpretations: what is first condemned as vulgar and inappropriate (like Meiji women's teyodawa kotoba) is subsequently recodified as prototypical feminine speech. Such reinterpretations barely conceal the discourse of power: the linguistic mechanisms of both medieval nyoobo kotoba and contemporary wakamono kotoba (youth language) are very similar and both can be thought of as linguistic fashions, but the former is iconized as the epitome of beautiful feminine language, and the latter as impertinent or immoral corruption.

Endō interprets current linguistic developments as evidence that the schism of gendered speech is reducing, and shared forms are increasingly common. And nevertheless, she notes that centuries of male-dominated discourse have left a deep trace in women's consciousness - they are afraid to "offend" when resisting the conventions of sexist language. While lauding the creative use of 
language by today's young girls, she concludes the book by expressing the hope that they will carry their "rebellion" into adulthood.

\section{Barbara Pizziconi}

SIMON MILLS:

Healing Rhythms: The World of South Korea's East Coast Hereditary Shamans.

(SOAS Musicology Series.) xii, 121 pp. CD. Aldershot: Ashgate, 2007. £27.50. ISBN 9870754658450.

Healing Rhythms: The World of South Korea's East Coast Hereditary Shamans is a study of the role, the beliefs, and the ritual practices of hereditary shamans and their instrumentalists in South Korea's Kangwŏn and Kyŏngsang provinces. Much of the work is based on Mills' PhD thesis, which in turn relied on extensive fieldwork performed by the author in 1999 and 2000. Since he began his fieldwork, Mills has studied with and occasionally performed alongside his two main informants, Kim Junghee and Jo Jonghun. Many of the comments included are taken from interviews conducted with them in early 2005 when they stayed at SOAS as "visiting research performers". The book consists of five chapters and a short conclusion, followed by a bibliography and a short index. On the audio CD, Kim, Jo and Mills can be heard performing the five key pieces discussed in each chapter.

In chapter one, "Türŏnggaengi - Who are the East Coast hereditary Mudang?", Mills introduces the realm of shamanist practice in South Korea, and in particular that of the Kim clan in the East Coast region to which his informants belong. Although Mills has been a participating observer of some of the rituals he describes, he does not dwell on how his being a foreigner may have affected his interpretations or his informants. He chooses, instead, to describe his experiences as objectively as possible, and gives fairly literal translations of sections from his interviews. When he indents a paraphrased rendition of his informants' words on their clan's heritage (p. 8), however, it seems he goes a little too far in trying to let them speak on their own behalf. Mills describes how some of his informants came to enter into the profession and what it implied in terms of their social position. He relates the differences between hereditary and charismatic shamans, and explains that even though some instrumentalists work for both kinds of shamans, they maintain their preferences (p. 18). He also reports some very interesting, negative experiences with Christians (p. 12). Because many aspects of Korean shamanism are introduced in a relatively short chapter, the narrative is a little patchy at times. This is exacerbated by the fact that throughout the book the names of illustrations and figures look exactly like sub-headings and that long tables are not broken up, resulting in the text on the preceding page ending well before the bottom of the page (see pp. 23, 27, 54).

Chapter two, "P'unŏri - musical practice in ritual", introduces the instruments used and explains their role in rituals. Unfortunately not all are accompanied by a picture, and because Mills does not always give descriptions of size and colour, some lay readers may be left wondering what they actually look like. The structure of the music, on the other hand, is given considerable attention. Mills provides long transcriptions of the main rhythmic cycles as played by the two instrumentalists and carefully describes the similarities and differences in style (pp. 42-55). I found the illustrations here very helpful, 